\title{
PELATIHAN PERTOLONGAN PERTAMA PADA ANAK TERSEDAK (CHOKING) DI MADRASAH IBTIDAIYAH AL FURQAN MUHAMMADIYAH CABANG 3 BANJARMASIN
}

\author{
Suci Fitri Rahayu ${ }^{1 *}$, Esme Anggeriyane ${ }^{2}$ \\ 1-2 Fakultas Keperawatan dan Ilmu Kesehatan \\ Universitas Muhammadiyah Banjarmasin
}

Email korespondensi: sucilovecat@gmail.com

\begin{abstract}
ABSTRAK
Tersedak merupakan suatu kondisi terjadinya sumbatan atau hambatan respirasi oleh benda asing yang menyempit pada saluran napas internal, termasuk faring, hipofaring, dan trakea. Penyempitan jalan napas bisa berakibat fatal jika itu mengarah pada gangguan serius oksigenasi dan ventilasi. Kondisi tersedak pada anak dapat menimbulkan situasi kegawatdaruratan respirasi yang jika tidak ditangani dengan segera dapat mengancam jiwa ataupun kecacatan anak. Penanganan yang dilakukan biasanya berhasil dan tingkat kelangsungan hidup sebesar 95\%. Untuk melakukan pertolongan terhadap kejadian ini diperlukan teknik Bantuan Hidup Dasar (BHD) penanganan tersedak. Teknik ini, selain harus dikuasai oleh petugas medis, juga penting diketahui oleh orang tua dan guru sebagai pertolongan pertama jika menemukan anak tersedak sebelum mendapatkan penanganan medis selanjutnya. Oleh karena itu orang tua perlu memiliki wawasan yang didapatkan dari pelatihan yang diberikan oleh tim tentang penatalaksanaan tersedak pada anak untuk mengurangi angka kejadian dan kemungkinan perburukan kondisi pada anak. Tujuan pengabdian masyarakat ini untuk mengetahui dan mengaplikasikan prosedur pertolongan pertama pada anak tersedak (choking). Metode pengabdian masyarakat ini dilakukan dengan ceramah, demonstrasi dengan alat peraga dan tanya jawab. Kesimpulan didapatkan orangtua dan guru mampu mengetahui dan mengaplikasikan pertolongan pertama pada anak tersedak (choking) sesudah diberikan pelatihan.
\end{abstract}

Kata Kunci: Pelatihan, Tersedak, Anak

\begin{abstract}
Choking is a condition of obstruction or obstruction of respiration by a narrowed foreign body in the internal airways, including the pharynx, hypopharynx, and trachea. The narrowing of the airway can be fatal if it leads to serious impairment of oxygenation and ventilation. Choking conditions in children can lead to respiratory emergencies which if not treated immediately can be lifethreatening or disabled. Treatment is usually successful and the survival rate is 95\%. To help with this incident, a Basic Life Support (BHD) technique is needed to deal with choking. This technique, besides having to be mastered by medical personnel, is also important for parents and teachers to know as first aid if they find a child choking before getting further medical treatment. Therefore, parents need to have the insight gained from the training provided by the team on the management of choking in children to reduce the incidence and possible worsening of the condition in children. The purpose of this community service
\end{abstract}


is to find out and apply first aid procedures to choking children. This community service method is carried out with lectures, demonstrations with props and questions and answers. The conclusion is that parents and teachers are able to know and apply first aid to choking children after being given training.

Keywords: Training, Choking, Children

\section{PENDAHULUAN}

Kasus kegawatan medis dapat terjadi dimana dan kapan saja. Kegawatan yang paling sering terjadi di area komunitas adalah kecelakaan yang diakibatkan oleh trauma, kegawatan pada kasus anak, dan henti jantung. Ketiga keadaan diatas memerlukan pertolongan yang baik dan segera sebelum pasien dibawa ke rumah sakit untuk perawatan definitif. Kesalahan memberikan pertolongan bisa membuat pasien menjadi lebih menderita dan meninggalkan kecacatan demi drajat kesehatan masyarakat yang meningkat

Tersedak merupakan suatu kondisi terjadinya sumbatan atau hambatan respirasi oleh benda asing yang menyempit pada saluran napas internal, termasuk faring, hipofaring, dan trakea. Penyempitan jalan napas bisa berakibat fatal jika itu mengarah pada gangguan serius oksigenasi dan ventilasi (Ain, 2019).

Menurut WHO (2011) sekitar 17.537 anak-anak berusia 3 tahun atau lebih muda mengalami situasi yang berbahaya karena tersedak, sebesar 59,5\% kejadian tersedak tersebut berhubungan dengan makanan, 31,4\% diakibatkan tersedak benda asing, dan sebesar 9,1\% penyebab lain tidak diketahui (Pandegirot et al., 2019). Prevalensi di Amerika Serikat didapatkan kasus tersedak pada anak usia dibawah 4 tahun sebesar 710, terjadi pada anak dibawah usia 1 tahun sebesar 11,6\%, kasus terjadi pada usia 1 hingga 2 tahun sebesar 36,2\% terjadi pada usia 2 tahun hingga 4 tahun sebesar 29,4\% (Suryani, 2019). Berdasarkan data dari Departemen Dinas Kesehatan Nasional menunjukkan penyebab tersedak adalah benda asing biji - bijian sejumlah 105 pasien, 82 pasien tersedak benda asing kacang - kacangan, sayuran 79 pasien, lainnya tersedak disebabkan oleh logam, makanan, dan tulang ikan (Sulistiyani \& Ramdani, 2020).

Kondisi tersedak pada anak dapat menimbulkan situasi kegawatdaruratan respirasi yang jika tidak ditangani dengan segera dapat mengancam jiwa ataupun kecacatan anak. Berdasarkan penelitian yang dilakukan oleh (R. P. Rahayu, 2014) tentang pengaruh pendidikan kesehatan terhadap tingkat pengetahuan orang tua dalam menangani anak tersedak di Desa Kedungsoka Pulo Ampel Serang Banten dengan jumlah responden 51 orang didapatkan hasil analisa bivariat menunjukkan bahwa tingkat pengetahuan orang tua sebelum diberikan pendidikan kesehatan adalah cukup sebanyak $56,9 \%$ dan hasil analisis data setelah diberikan pendidikan kesehatan tingkat pengetahuan orang tua adalah baik sebanyak 41,2\%. Analisa bivariat dengan menggunakan uji Wilcoxon Signed Rank Test diperoleh p-value sebesar 0,000< a 0,005.

Penanganan yang dilakukan biasanya berhasil dan tingkat kelangsungan hidup sebesar 95\%. Untuk melakukan pertolongan terhadap kejadian ini diperlukan teknik Bantuan Hidup Dasar (BHD) penanganan tersedak. Teknik ini, selain harus dikuasai oleh petugas medis, juga penting diketahui oleh orangtua sebagai pertolongan pertama jika menemukan anak tersedak sebelum mendapatkan penanganan medis selanjutnya. Oleh karena itu 
orangtua perlu memiliki wawasan yang didapatkan dari penyuluhan yang diberikan oleh tim tentang pencegahan dan penatalaksanaan tersedak pada anak di rumah untuk mengurangi angka kejadian dan kemungkinan perburukan kondisi pada anak (Ain, 2019).

Tujuan pengabdian masyarakat ini untuk mengetahui dan mengaplikasikan prosedur pertolongan pertama pada anak tersedak (choking).

\section{MASALAH}

Alasan kami memilih tempat kegiatan di Madrasah Ibtidaiyah Al Furqan Muhammadiyah Cabang 3 Banjarmasin karena di Banjarmasin, sekolah dengan jumlah murid lebih banyak daripada sekolah lainnya. Selain itu fasilitas kesehatan terdekat seperti Puskesmas itu membutuhkan waktu 15 - 20 menit sehingga jika ada korban dengan tersedak maka akan sulit untuk dipertahankan jika harus di transfer Puskesmas terlibih dahulu. Selain itu, pengetahuan orangtua dan guru tentang pertolongan tersedak pada anak sangat minim. Tujuan khusus dari pelatihan singkat ini adalah peserta mengetahui dan mengaplikasikan prosedur pertolongan pertama pada anak tersedak (choking). Berikut peta lokasi kegiatan:

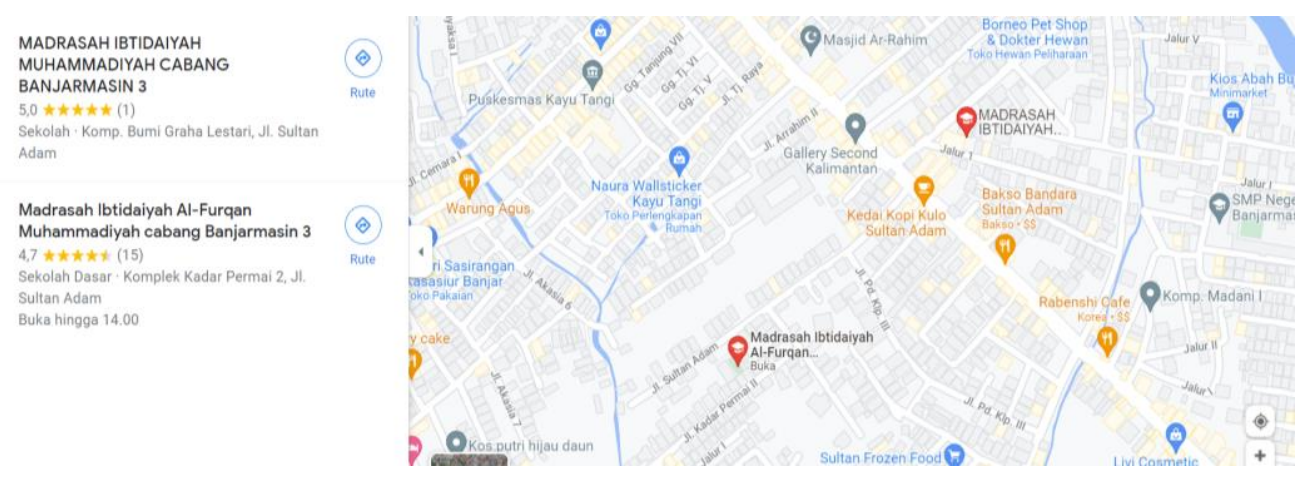

2.1 Gambar Lokasi Kegiatan

\section{METODE}

Metode pengabdian masyarakat ini dilakukan dengan ceramah, demonstrasi dengan alat peraga dan tanya jawab. Dimulai dari tahap persiapan yaitu koordinasi dengan Dinas Pendidikan dan Sekolah, menetapkan waktu pelaksanaan untuk kegiatan, tahap pelaksanaan yaitu persiapan peserta, mengisi daftar hadir, peserta menggambil tempat duduk, mendiskusikan kontrak waktu, pretest, kegiatan pelatihan (Materi dan Video), demonstrasi (Praktikum), menanyakan kembali kepada peserta mengenai semua materi yang telah diberikan (feed back), memberikan reinforcement dan reward kepada peserta, posttest dan terminasi. Kegiatan ini diikuti oleh orangtua dan guru sejumlah 20 orang. 


\section{HASIL DAN PEMBAHASAN}

Hasil

Kegiatan pengabdian masyarakat ini menggunakan pretest dan posttest untuk evaluasi akhir. Hasil skor pretest dan posttest tercantum dalam tabel dibawah berikut:

\begin{tabular}{|c|c|c|}
\hline NO & Skor Pretest & Skor Posttest \\
\hline 1 & 30 & 90 \\
\hline 2 & 40 & 100 \\
\hline 3 & 30 & 90 \\
\hline 4 & 20 & 80 \\
\hline 5 & 30 & 90 \\
\hline 6 & 30 & 90 \\
\hline 7 & 40 & 100 \\
\hline 8 & 50 & 100 \\
\hline 9 & 40 & 90 \\
\hline 10 & 30 & 90 \\
\hline 11 & 20 & 80 \\
\hline 12 & 20 & 80 \\
\hline 13 & 30 & 90 \\
\hline 14 & 40 & 90 \\
\hline 15 & 40 & 90 \\
\hline 16 & 30 & 80 \\
\hline 17 & 20 & 80 \\
\hline 18 & 20 & 90 \\
\hline 19 & 50 & 100 \\
\hline 20 & 30 & 90 \\
\hline
\end{tabular}

\section{Pembahasan}

Berdasarkan hasil pretest dan posttest didapatkan terdapat peningkatan pengetahuan dan keterampilan bagi orangtua dan guru pada kegiatan pelatihan pertolongan pertama pada anak tersedak (choking).

Pelatihan merupakan proses pendidikan jangka pendek yang menyatukan pembelajaran secara teori dan praktek, sehingga pelatihan merupakan faktor yang dapat meningkatkan pengetahuan seseorang (Larasati, 2018). Pelatihan dapat mempengaruhi pengetahuan secara signifikan karena memiliki faktor-faktor pendukung. Salah satu faktor yang menjadikan pelatihan dengan metode simulasi dapat meningkatkan pengetahuan yaitu karena peserta dibimbing langsung oleh pelatih yang telah memiliki sertifikat provider. Hal ini sejalan dengan penelitian (Sutono et al., 2016) yang menyatakan pelatihan dengan umpan balik pelatih dapat langsung memberikan koreksi dan perintah jika dalam melakukan prosedur kurang tepat. Selain itu, peserta dapat secara langsung bertanya, sehingga peserta akan lebih paham dalam proses pelatihan.

Berdasarkan pengabdian yang dilakukan (S. F. Rahayu et al., 2021), dari hasil pendidikan kesehatan, guru mengalami peningkatan pengetahuan dan wawasan terlihat dari hasil pretest dan posttest.
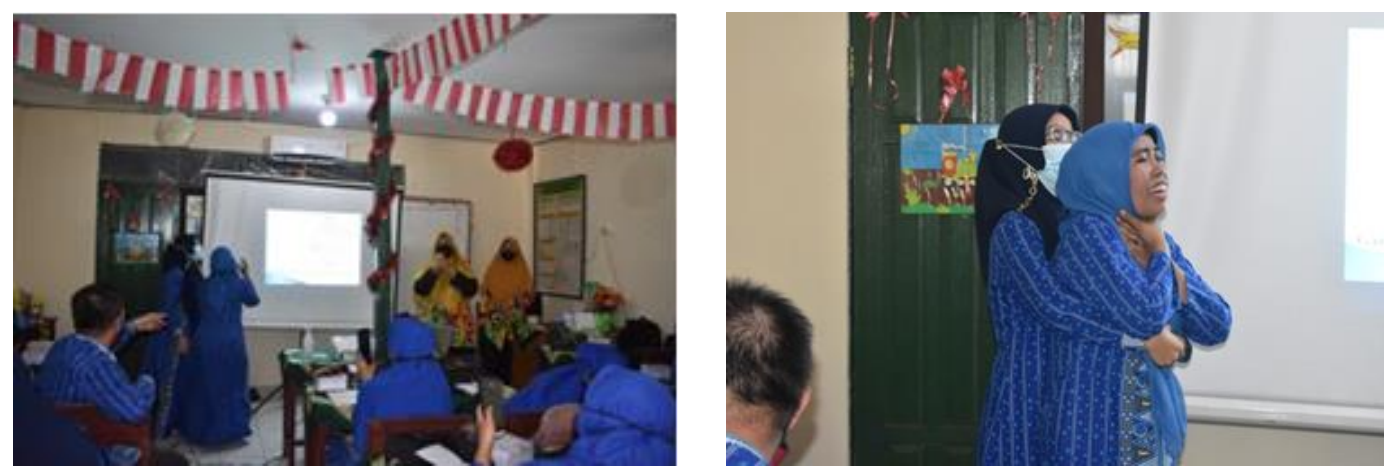

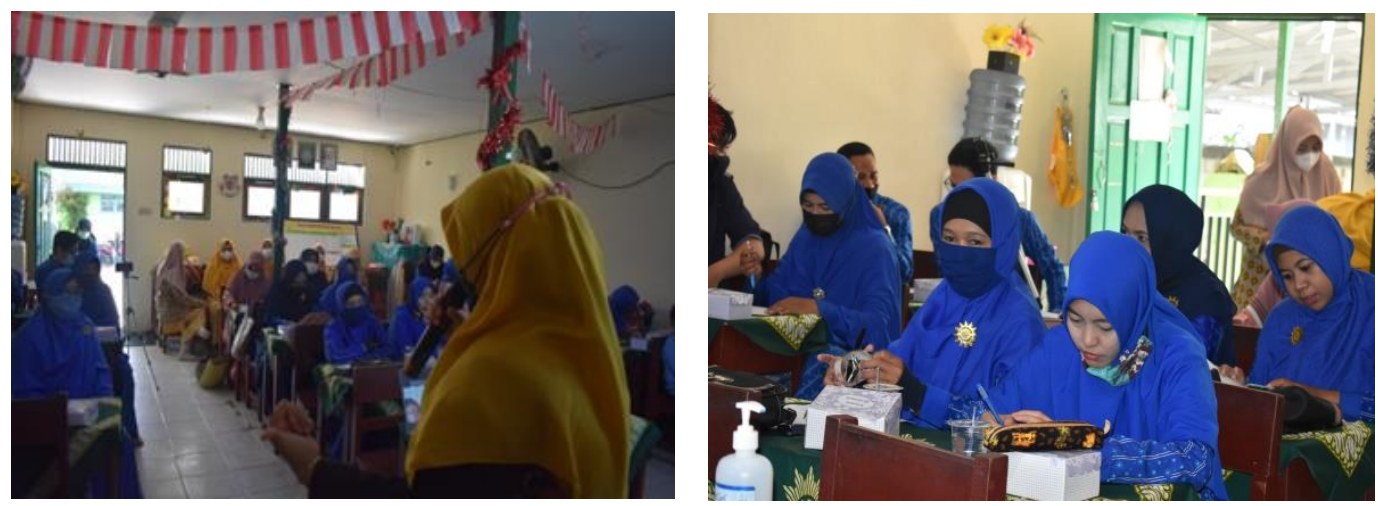

Selain edukasi melalui pelatihan melalui konsep simulasi terdapat beberapa metode lain dalam meningkatkan pengetahuan, diantaranya yaitu melalui video. Pelatihan menggunakan video memiliki kelebihan tersendiri yaitu peserta dapat belajar secara mandiri menggunakan video dimana saja dan kapan saja. Berdasarkan penelitian yang dilakukan oleh (Metrikayanto et al., 2018) edukasi melalui video merupakan inovasi dalam pelatihan bantuan hidup dasar. Pengabdian masyarakat ini menjelaskan bahwa pelatihan melalui video merupakan metode yang efektif dalam mengajarkan masyarakat awam terkait pertolongan pertama pada anak tersedak (choking).

Pelatihan merupakan konsep belajar yang berfokus kepada keterampilan. Pelatihan membentuk dasar dari pelaksanaan keterampilan seseorang. Pelatihan seharusnya menjadi hal yang berkesinambungan dengan tujuan mengingat serta memperbarui lagi pengetahuan dan keterampilan yang dimiliki.

Faktor lain yang membuat keterampilan responden meningkat secara signifikan yaitu tidak terlepas dari penggunaan phantom sebagai alat peraga. Berdasarkan penelitian yang dilakukan (Andita, 2018) yaitu pengaruh pendidikan kesehatan sadari dengan media slide dan benda tiruan terhadap perubahan pengetahuan didapatkan hasil penggunaan alat tiruan (phantom) dapat meningkatkan pengetahuan dan keterampilan seseorang.

Penggunaan alat peraga dapat membuat responden seolah-olah menolong korban sesungguhnya. Selain itu, dengan menggunakan alat peraga maka akan semakin banyak panca indera yang digunakan sehingga informasi dan keterampilan yang didapat akan lebih banyak. Namun, peran pelatih masih sangat dominan karena keberadaan phantom hanya sebagai sarana untuk demonstrasi skill. Keterampilan dapat dibentuk melalui pelatihan melalui berbagai media. Semakin banyak media yang digunakan maka keahlian dan retensi pengetahuan akan lebih berkualitas.

\section{KESIMPULAN}

Kesimpulan didapatkan orangtua dan guru mampu mengetahui dan mengaplikasikan pertolongan pertama pada anak tersedak (choking) sesudah diberikan pelatihan. Kegiatan selanjutnya agar menjangkau lebih luas lagi sasaran peserta. 


\section{DAFTAR PUSTAKA}

Ain, H. (2019). Penanganan Sumbatan Benda Asing Pada Anak Berbasis Critical Care Caring. Media Sahabat Cendikia.

Andita, U. (2018). Pengaruh Pendidikan Kesehatan Sadari Dengan Media Slide Dan Benda Tiruan Terhadap Perubahan Pengetahuan Wus. Jurnal Promkes, 4(2), 177. https: / /doi.org/10.20473/JPK.V4.I2.2016.177-187

Larasati, S. (2018). Manajemen Sumber Daya Manusia -. http://repository.umpalembang.ac.id/id/eprint/6624/

Metrikayanto, W. D., Saifurrohman, M., \& Suharsono, T. (2018). Perbedaan Metode Simulasi dan Self Directed Video Terhadap Pengetahuan,Sikap dan Ketrampilan Resusitasi Jantung Paru(RJP) Menggunakan I-Carrer Cardiac Resuscitation Manekin Pada Siswa SMA Anggota Palang Merah remaja (PMR). Care: Jurnal Ilmiah Ilmu Kesehatan, 6(1), 79-91. https://doi.org/10.33366/CR.V6I1.792

Pandegirot, J. S., Posangi, J., \& Masi, G. N. M. (2019). Pengaruh Penyuluhan Kesehatan Tentang Penanganan Tersedak Terhadap Pengetahuan Ibu Menyusui. Jurnal Keperawatan, 7(2). https: / /ejournal.unsrat.ac.id/index.php/jkp/article/view/27473

Rahayu, R. P. (2014). Pengaruh Pendidikan Kesehatan Terhadap Tingkat Pengetahuan Orangtua Dalam Menangani Anak Tersedak di Desa Kedungsoka Puloampel Serang Banten. http://repository.unjaya.ac.id/957/1/Rika Puji Rahayu_3210017_nonfull.pdf

Rahayu, S. F., Anggeriyane, E., \& Mariani, M. (2021). Upaya Penguatan Program Stimulasi, Deteksi Dan Intervensi Dini Tumbuh Kembang (Sdidtk) Melalui Pemeriksaan Antropometri Pada Anak Prasekolah. Jurnal EMPATI (Edukasi Masyarakat, Pengabdian Dan Bakti), 2(1), 71-75. https://doi.org/10.26753/EMPATI.V2I1.522

Sulistiyani, A.-, \& Ramdani, M. L. (2020). The Influence of Health Education about Handling Choking on Children through Booklet Media on the Knowledge Level of Posyandu Cadres in Karangsari Village. Jurnal Ilmiah Keperawatan Indonesia [JIKI], 4(1), 11. https://doi.org/10.31000/JIKI.V4I1.2826

Suryani, rahmawati. (2019). Studi Kasus Pengetahuan Orangtua Tentang Pertolongan Pertama Choking Pada Balita Di Desa Geyer Kecamatan Geyer Kabupaten Grobogan. Ejournal the Shine Cahaya Dunia S1 Keperawatan, 4(1), 1-8.

Sutono, S., Ratnawati, R., \& Suharsono, T. (2016). Perbedaan Nilai Kompresi Dada Dan Ventilasi Pada Pelatihan Resusitasi Jantung Paru Mahasiswa S1 Keperawatan Dengan Umpan Balik Instruktur, Audiovisual Dan Kombinasi Di Yogyakarta. Jurnal Ilmu Keperawatan: Journal of Nursing Science, 3(2), 183-197. https://jik.ub.ac.id/index.php/jik/article/view/47/56 